\title{
Teknokentte Faaliyet Gösteren Bir Firmanın Ar-Ge Faaliyetlerinin MSUGT, BOBİ FRS ve TMS/TFRS Tam Set Kapsamında Muhasebeleştirilmesi ${ }^{1}$
}

\author{
Esin KENDİR ${ }^{2 *}$, Burcu ASLANTAŞ ATEŞ ${ }^{3}$
}

Geliş Tarihi/Received: 03.10.2020

Kabul Tarihi/Accepted: 27.10.2020

Araştırma Makalesi/Research Article

\section{ÖZET}

Araştırma geliştirme (Ar-Ge); "yazılım dâhil olmak üzere yeni süreç, sistem ve uygulamalar tasarlayarak sistematik bir temelde yürütülen yaratıcı çalışmalardır". Teknoloji geliştirme bölgeleri (teknokentler) ise; Ar-Ge çalışmalarının sürdürülmesi, katma değerli ürünlerin ortaya çıkarılması amacıyla bilgi ve teknoloji transferinin gerçekleştirildiği araştırma merkezleridir. Etkili bir bilim ve teknoloji politikası uygulamak isteyen ülkeler teknokentler kurarak Ar-Ge faaliyetlerine imkân yaratırlar. Teknokentlerde Ar-Ge faaliyetlerinin daha rahat ve rekabetçi bir ortamda gerçekleşebilmesi için ülkemizde de 26.06.2001 tarihli 4691 sayılı Teknoloji Geliştirme Bölgeleri Kanunu kapsamında Teknoloji Geliştirme Bölgeleri kurulmuştur. Buna dayanarak bu çalışmada teknokentlerde faaliyet gösteren firmaların Ar-Ge faaliyetlerinin muhasebe kayıtlarını incelemek amaçlanmıştır. Söz konusu kayıtları Muhasebe Sistemi Uygulama Genel Tebliği (MSUGT), Türkiye Muhasebe Standartları/ Türkiye Finansal Raporlama Standartları Tam Set (TMS/TFRS Tam Set) ile Büyük ve Orta Büyüklükteki İşletmeler İçin Finansal Raporlama Standartları (BOBİ FRS) kapsamında karşılaştırmalı olarak gösterebilmek amacıyla Isparta Göller Bölgesi Teknokenti’ nde faaliyet gösteren bir firma üzerinde araştırma yapılmıştır.

Anahtar kelimeler: Muhasebe, İnovasyon ve Buluş: Süreçler ve Teşvikler, Teknolojik İnovasyon ve AR-GE Yönetimi, Teknolojik Yenilik

\footnotetext{
${ }^{1}$ Bu çalışma, Doç. Dr. Burcu ASLANTAŞ ATEŞ danışmanlığında Süleyman Demirel Üniversitesi Sosyal Bilimler Enstitüsünde yürütülen "Teknokentlerde faaliyet gösteren firmalarda $\mathrm{Ar}-\mathrm{Ge}$ faaliyetlerinin muhasebeleștirilmesi” başlıklı Yüksek Lisans tezinden üretilmiștir.

${ }^{2}$ Doktora Öğrencisi, Süleyman Demirel Üniversitesi, Sosyal Bilimler Enstitüsü, Bankacılık ve Finans Anabilim Dal1, Orcid No: 0000-0003-0435-7499

* Sorumlu yazar/Corresponding author

E-mail/e-ileti: esinkendir@hotmail.com

${ }^{3}$ Doç. Dr., Süleyman Demirel Üniversitesi, İktisadi ve İdari Bilimler Fakültesi, Finans ve Bankacılık Bölümü, Orcid No: 0000-0002-8896-5303
} 


\title{
Accounting of R\&D Activities Of A Company Operating in Science Park Under The Scope of Accounting System Applications General Communique (MSUGT), FRS for LMEs/BOB FRS and TAS / TFRS
}

\begin{abstract}
Research and development (R\&D) is; creative works that carried out on a systematic basis by designing new processes, systems and applications, including software. Technology development zones (Science Parks) are; research centers where information and technology transfer is carried out in order to continue R\&D studies and create value-added products.. Countries that want to implement an effective science and technology policy create opportunities for R\&D activities by installing technocities. Technology Development Zones have been established within the scope of Technology Development Zones Law No. 4691 dated 26.06.2001 in order to realize $R \& D$ activities in a more comfortable and competitive environment in Science Parks in our country. Based on this, in this study, it was aimed to examine the accounting records of the $R \& D$ activities of companies which operating in science parks. With aim to show comparatively the records in question within the scope of Accounting System Applications General Communique, Turkey Accounting Standards / Turkey Financial Reporting Standards Full Set and the Financial Reporting Standard for Large and Medium Size Enterprises, it is made researched on a company which operating in Isparta Lakes Region Technocity.
\end{abstract}

Keywords: Accounting, Innovation and Invention: Processes and Incentives, Management of Technological Innovation and R\&D, Technological Innovation.

\section{GíRiş}

İşletmelerin hayatlarını sürdürebilmeleri bakımından rekabet edebilir olmanın önemi tartışılamaz. Aynı zamanda işletmeler rekabeti sağlamak için maliyet liderliği, yeni ürün geliştirme, pazarı çeşitlendirme gibi yollar izleyebilir. Yeni ürün geliştirip yeni pazarlardan pay almak araştırma geliştirme (Ar-Ge) çalışmaları ile mümkün olabilir. Aynı zamanda Ar-Ge faaliyetlerine önem verilmesi bilgi ve teknolojiyi geliştirme açısından da önemlidir. Ülkeler teknolojiyi dışarıdan sağlamak yerine kendi teknolojisini üretmek isterse bunu Ar-Ge faaliyetleriyle sağlayabilir. Yeni bilgi ve buluşların günümüz ekonomisinin büyüme ve kalkınması açısından etkili olması Ar-Ge faaliyetlerine çok daha önem verilmesi gerektiğini ortaya koymaktadir. 
Ar-Ge faaliyetleri çoğu zaman teknokentler bünyesinde yapilabilmektedir. Teknokentler, teknolojiye bağlı işletmelerin oluşumunda ve gelişiminde, üniversiteler ile ileri teknoloji merkezi, Ar-Ge merkezi veya enstitüsü kuruluşlarını bir araya getirerek bilimsel çalışmaların uygulanmasında önemli bir role sahiptir. Türkiye'de teknokentlerde Ar-Ge faaliyetlerinin gerçekleşmesi, üniversite ve diğer Ar-Ge faaliyetinde bulunan bazı kuruluşlarla sanayinin ortak çalışmasını teşvik etmek amacıyla 2001 yılında 4691 Sayılı Teknoloji Geliştirme Bölgeleri Kanunu çıkarılmıştır. Buna dayanarak ülkemizde Teknokentler kurulmuş olup; bunlardan biri olan Isparta Göller Bölgesi Teknokenti'nde faaliyet gösteren bir firma, bu çalışmanın konusunu oluşturmuştur.

\section{INOVASYON VE ARAŞTIRMA GELIŞTIRME}

Latince "innovatus" kelimesinden türetilen inovasyon kelimesi (Bulut ve Arbak, 2012: 1), İngilizcede “innovation” olup dilimize tam karşılığını vermemekle birlikte yenileme, yenilenme, yenileşme, yenileşim gibi anlamlarda kullanılmakta, "yeni bir şey yapmak" anlamını da taşımaktadır (Biçkes, 2011: 73). Dilimizde yine yenilik ve yenilikçilik gibi sözcüklerle de karşımıza çıkan inovasyon, yeniliğin kendisinden daha önce sonucunu; farklılaştırma ve değiştirmenin olduğu ekonomi ve toplumu içeren bir sistemi anlatır (Elçi, 2007: 1).

Ekonomik İş Birliği ve Kalkınma Örgütü (OECD) tarafından yayınlanan Oslo El kitabına (2005: 46) göre inovasyon, “iş uygulamalarında, işyeri organizasyonunda veya dış ilişkilerde yeni ya da önemli ölçüde geliştirilmiş bir mal ya da hizmetin, sürecin, yeni bir pazarlama yönteminin veya yeni bir örgütsel yöntemin uygulanmasıdır". Drucker (1984) inovasyonu "bir örgütte beraber çalışan farklı bilgi ve yetenekteki insanlarl verimli hale getirmek için onlara ilk defa imkân sağlayan yararlı bilgi" ş̧eklinde tanımlamıştır. Aleinikoff (2014: 8) ise inovasyon için şunları söylemiştir; yenilikçilik, çoğunluğun fikrinden faydalanmaya çalışılan (kurum içi ve dışından alınan "çoğunluk" ile) yeni eğilimlere ve ürünlere dayanan değişim ve problem çözme stratejisidir. Diğer bir tanımla inovasyon; “firmalarda dinamik problem çözme yöntemidir” Rosenfeld (2012: 1) için inovasyon, değişimi bir firsat olarak görme yeteneğidir Rogers (1971: 11) ise inovasyonu, "bir birey (girişimci) tarafindan yeni olarak algılanan bir fikir, uygulama veya nesne” olarak tanımlamıştır.

Yalnızca şirketler açısından değil ülkeler açısından da piyasada rekabet üstünlüğü sağlayabilmek bilim ve teknoloji alanına yönelmek ile mümkün olabilir. Bilim ve teknolojide rekabet avantajı yakalamış ülkeler gelişmiş ülke olmanın koşullarından birini gerçekleştirmiş 
olur (IMF, 2011) ve ülkelerin refah seviyelerini bilim ve teknoloji politikalarının da doğrudan etkilediği karşımıza çıkmaktadır. Hâliyle bilim ve teknoloji, ülkelerin ekonomik kalkınma ve büyümelerine yönelik en önemli itici güç olarak kabul edilir. Gelişmiş ülkeler ise, uluslararası arenada birden fazla alanda lider olabilmenin ve özellikle iktisadi anlamda etkin rol almanın, etkili bir bilim ve teknoloji politikası ve araştırma imkânlarına sahip olmasıyla sağlanabileceğinin farkındadır (Kaynak, 2011: 151). Dolayısıyla da ülkeler bu imkânlar aracılığıyla teknolojiye ulaşmak, kullanmak ve geliştirmek ister. $\mathrm{Bu}$ nedenle son yıllarda “İnovasyon” ve "Ar-Ge” kavramları sık sık kullanılmaya başlanmıştır. Ar-Ge, yeni bir bilginin geliştirilmesiyle başlayarak (Öner, 2006: 6) yeni bir ürünün tasarımı ve bu ürünün üretim süreçlerinin geliştirilmesiyle birlikte işletmenin ihtiyacı olan; pazarlama, finansman ve iş gücünün temin edildiği yaratıcı çalışmaların bütünü olarak ifade edilmektedir (Tuncer, 2010: 18).

Ar-Ge ve inovasyon, ülkeler veya bölgeler için sürdürülebilirlik yönünden kalkınmanın sağlanmasında, toplumsal refahın hızla artırılmasında ve yaşam kalitesinin oldukça yükseltilerek bölgeler arasındaki farklılıkların olabildiğince en az seviyeye indirilmesinde önemli bir kavram olarak görünür. İnovasyon ayrıca yeni ürün ve fikirlere yönelik olarak mevcut potansiyel üzerinde ilerlemeler sağlamaktadır. Ar-Ge ve teknoloji faaliyetleriyle inovasyon bütünleşerek girişimcilere sektörel yönden yeni olanak ve firsatlar dâhilinde bir ülkenin veya bölgenin gelişmesine katkı sağlamaktadır (Porter, 1990: 22).

\section{TEKNOKENTLER}

Ülkelerin Ar-Ge yatırımları ve harcamaları teknolojik gelişmelerin sağlanabilmesi açısından önemli bir gösterge olarak kabul edilmektedir (Çaltekin, 2014: 1). Bu sebeple çoğu ülke küresel ekonomi içinde yerlerini sağlamlaştırmak veya yeni bir konum elde etmek amacıyla teknolojik ilerlemeye katkı sağlayacak uygulamalara yönelmektedir. Teknokentler de, teknolojinin geliştirildiği bölgeler (Kayalıdere, 2014: 88) olarak teknolojiye bağlı işletmelerin oluşumunda ve gelişiminde önemli bir role sahiptir. Üniversiteler ile ileri teknoloji, Ar-Ge merkezi veya enstitüsü kuruluşlarını bir araya getirerek bilimsel çalışmaların uygulanmasına olanak tanır. Teknokentler; yeni girişimlerin büyümesine ve ekonomik kalkınmanın geliştirilmesine yardımcı olan, sanayi ortaklıkları aracılığıyla üniversitenin araştırma ve geliştirmesini desteklemede rol alan, etkin çalışma koşulları ile verimliliğin artırılması ve uluslararası alanda rekabet gücünün yükseltilmesi amacıyla kurulan topluluklardır (Kızıltaş, 2006: 29). 
Teknokentlerin amaçları, kurucularına ve teknokentlerin kuruluş politikalarına göre farklılıklar gösterir. Kamu yönetimi tarafından sağlanan bölgesel ekonomik kalkınmanın parçası olan teknokentler yeni iş olanakları yaratmayı amaçlarken; üniversiteler tarafından kurulan teknokentlerde, Ar-Ge çalışmalarına önem verilmektedir (Güney, 2010).

Ülkemizde teknokentlerle ilgili ilk ciddi ve bağımsız yasal düzenleme "26.06.2001 tarih ve 4691 sayılı Teknoloji Geliştirme Bölgeleri Kanunu”nun yayımlanması ile başlamıştır. Bu kanunun yayımlanmasından bir yıl sonra da Uygulama Yönetmeliği yürürlüğe konulup sistem tamamlanmıştır. Teknokentlerin bu girişimden sonra kurulup gelişmesi tamamlanmış ve bu tür kuruluşların sayısı hızla artmaya başlamıştır. Bu bölgelerin büyümesi ve gelişmesi için altyapı ve üstyapı çalışmalarının yanında çeşitli vergisel teşviklere de ihtiyaç duyulmaktadır (Tuncer, 2010: 206).

4691 sayılı Teknoloji Geliştirme Bölgeleri Kanunu'nda Ar-Ge, yazılım ve tasarım faaliyetleri ile ilgili olarak önemli vergisel avantajlar yer almaktadır. Bunlar (4691 Sayılı Kanun Metni, 2001);

- Teknokentlere özel olarak uygulanmakta olan gelir ve kurumlar vergisi istisnas1,

- $\quad$ Katma değer vergisi istisnas1,

- Teknokentlerde çalışan personellere ödenen ücretlerdeki vergisel teşvikler,

- $\quad$ Damga vergisi ve harç istisnası.

Girişimciler, teknokentlerde yaptıkları yatırımlar ile teknolojik gelişme açısından ülke ekonomisine büyük katkı sağladığından dolayı teknoloji geliştirme bölgelerinde faaliyet gösteren girişimcilere önemli ölçüde teşvikler sunulması gerekmektedir (Eren, 2011: 89). Buna göre 4691 sayılı Kanunun geçici 2. Maddesinin birinci paragrafi; "bölgede faaliyet gösteren gelir ve kurumlar vergisi mükelleflerinin, bölgedeki yazllım ve Ar-Ge faaliyetlerinden elde ettikleri kazançları 31.12.2023 tarihine kadar gelir ve kurumlar vergisinden müstesna tutulduğu”nu belirtmiştir (4691 Sayılı Kanun Metni, 2001).

Bununla birlikte teknokentlerde görülen bazı teslim ve hizmetler KDV'den istisna tutulmuştur. Bu kurala uygun olarak; 3065 sayılı Katma Değer Vergisi (KDV) Kanunu'na 5035 sayılı Kanun'un 11. maddesiyle eklenen ve 01.01.2014 tarihinde itibaren yürürlüğe giren geçici 20. maddesinin (1) numaralı fikrasında “4691 sayılı Teknoloji Geliştirme Bölgeleri Kanunu’na göre teknoloji geliştirme bölgesinde faaliyette bulunan girişimcilerin kazançlarının gelir veya kurumlar vergisinden istisna bulunduğu süre içinde münhasıran bu bölgelerde ürettikleri ve 
Kendir, E., Aslantaş Ateş, B.

sistem yönetimi, veri yönetimi, iş uygulamaları, sektörel, internet, mobil ve askeri komuta kontrol uygulama yazılımı şeklindeki teslim ve hizmetleri katma değer vergisinden müstesna" olduğu (Bezirci, 2012: 55) ve "Maliye Bakanlı̆̆l program ve lisans türleri itibariyle istisnadan yararlanılacak bedele ilişkin olarak asgari sınır belirlemeye, istisna uygulanacak yazllım programlarını tanımlamaya ve uygulamaya ilişkin usul ve esasları tespit etmeye yetkilidir." hükmü yer almaktadır (Tan ve Erdem, 2010: 150, 3065 Sayılı Katma Değer Vergisi Kanunu, 1984).

4691 sayılı Teknoloji Geliştirme Bölgeleri Kanunu’nun 01.01.2004 yılı geçici 2. maddesi hükmüne göre; "Yönetici şirketlerin bu kanun uygulaması kapsamında elde ettikleri kazançlar ile bölgede faaliyet gösteren gelir ve kurumlar vergisi mükelleflerinin, münhasıran bu bölgedeki yazllım ve Ar-Ge faaliyetlerinden elde ettikleri kazançları 31.12.2013 tarihine kadar gelir ve kurumlar vergisinden müstesnadır", şeklini almıştır. Daha sonra, 02.03.2011 tarih ve 6170 sayılı Teknoloji Geliştirme Bölgeleri Kanununda Değişiklik Yapılmasına Dair Kanun (2011) ile son halini alan geçici 2.madde hükmüne göre ise; "Bölgede çalışan; Ar-Ge ve destek personelinin bu görevleri ile ilgili ücretleri, 31/12/2023 tarihine kadar her türlü vergiden müstesnadır. Muafiyet kapsamındaki destek personeli sayısı Ar-Ge personeli sayısının yüzde onunu aşamaz." şeklinde değiştirilmiştir. Kanun maddesinde "her türlü vergiden" ibaresine yer verilmiş olması nedeniyle "yukarıda belirtilen kimselerin gelir vergisi dişında diğer vergilerden de; örneğin, damga vergisinde de istisna hükümlerinden yararlanması gerektiği" düşünülmektedir. Yine kanun maddesinde "bu istisnanın uygulanmasında yönetici şirket, ücreti gelir vergisi istisnasından yararlanan kişilerin bölgede fiilen çalışıp çalışmadığını" denetler (Tan ve Erdem: 150, 6170 Sayılı Teknoloji Geliştirme Bölgeleri Kanununda Değişiklik Yapılmasına Dair Kanun, 2011).

Ar-Ge, yazılım ve tasarım faaliyetlerinin desteklenmesi ile ilgili teşviklerden faydalanılabilmesi için faaliyetin bölge içerisinde olması gerekmektedir. Fakat faaliyet konusu ne olursa olsun Kamu Gözetim Kurumu (KGK), bünyesinde bahsi geçen işletmelerin faaliyetlerini muhasebeleştirme işlemlerinde belirli standartlar çerçevesinde muhasebe işlemlerini uygulamayı zorunlu tutmuştur. 2014 yılında ise, TMS/TFRS Tam Set uygulamaları ile ilgili "sadece Kamu Yararını İlgilendiren Kuruluşları (KAYİK)" zorunlu tutmuştur. Karar metine göre; TMS/TFRS Tam Setin uygulama kapsamı; "6/12/2012 tarihli ve 6362 sayll Sermaye Piyasası Kanunu uyarınca Sermaye Piyasası Kurulunun düzenleme ve denetimine tabi işletmelerden, 19/10/2005 tarihli ve 5411 sayıl Bankacılık Kanunu uyarınca Bankacılık Düzenleme ve Denetleme Kurumunun düzenleme ve denetimine tabi işletmelerden, 3/6/2007 
tarihli ve 5684 sayılı Sigortacılık Kanunu ile 28/3/2001 tarihli ve 4632 sayll Bireysel Emeklilik Tasarruf ve Yatırım Sistemi Kanunu kapsamında faaliyet göstermekte olan sigorta ve emeklilik şirketlerinden, Borsa İstanbul Piyasalarında faaliyet göstermesine izin verilen; yetkili müesseseler, klymetli madenler aracı kurumları, klymetli maden üretimi veya ticareti ile Isştigal eden anonim şirketlerinden" oluşmaktadır. Fakat KGK, TMS/TFRS Tam Set uygulamayan işletmeler için MSUGT' lerini yine KGK'nın 29/12/2014 tarihli ve 41 sayılı kararı uyarınca "Finansal Tablolarının Hazırlanmasında Uygulanacak İlave Hususlar" ile birlikte uygulayarak raporlama yapılmasını istemiştir.

KGK tarafindan TMS/TFRS Tam Sete göre daha şeffaf ve anlaşılır olması, maliyet yükünün daha düşük olması, karşılaştırılabilir ve Avrupa Birliği direktifleriyle daha uyumlu olması BOBİ FRS'yi yayımlamıştır. Dolayısıyla BOBİ FRS' yi tercih eden bağımsız denetime tâbi firmalar MSUGT'ye bağlı kalma sorumluluklarını ortadan kaldırmış, bu standardı tercih eden firmalar 01.01.2018 tarihinden itibaren standardı uygulamaya tercih hakkı kazanmıştır.

Standart BOBİ FRS’ yi uygulayacak işletmeler için 4. Maddesinde açıklama yapmış, bu açıklamaya göre “19/12/2012 tarihli ve 2012/4213 sayllı Bakanlar Kurulu Kararl ile yürürlüğe konulan Bă̆ımsız Denetime Tabi Olacak Şirketlerin Belirlenmesine Dair Karar uyarınca bağımsız denetime tabi olup, 26/8/2014 tarihli ve 29100 sayılı Resmî Gazete' de yayımlanan Kurul Kararı kapsamında TMS/TFRS Tam Set uygulamayan işletmelerin finansal tablolarının hazırlanmasında BOBI FRS' yi uygulamasını zorunlu kılmıştır”. Bununla birlikte standart 5. Maddesinde “ BOBI FRS' yi uygulayan işletmeler için iki yll geçmedikçe isteğe bağll olarak TMS/TFRS Tam Seti" uygulayamayacaklarından; diğer taraftan "isteğe bağll olarak TMS/TFRS Tam Seti uygulayan işletmelerin BOBI FRS' yi uygulayabilmeleri için en az iki yıl TMS/TFRS Tam Seti uygulamış olması" zorunluluğundan bahsetmiştir.

\section{UYGULAMA}

\subsection{Uygulamanın Amacı}

Teknokentlerde faaliyet gösteren firmaların Ar-Ge faaliyetleri ile "4691 Sayılı Teknoloji Geliştirme Bölgeleri Kanunu (TGBK)” kapsamında tanınan istisna ve teşviklerin muhasebe kayıtlarını incelemek temel amacıyla yola çıkılan bu çalışmada, Isparta Göller Bölgesi Teknokenti'nde faaliyet gösteren bir firmanın Ar-Ge faaliyetleri incelenmiştir. Bu firmanın Ar-Ge faaliyetleri ile ilgili kayıtları 4691 Sayılı kanun kapsamında MSUGT, TMS/TFRS Tam Set ve BOBİ FRS' ye göre karşılaştırılmalı olarak incelenmiştir. 
Kendir, E., Aslantaş Ateş, B.

\subsection{Uygulamanın Yöntemi}

4691 sayılı kanun kapsamındaki istisna ve teşviklerin Ar-Ge faaliyetinde bulunan firmaların muhasebe kayıtlarında ne şekilde yer aldığını incelemek amacıyla Isparta Göller Bölgesi Teknokenti'nde Ar-Ge faaliyetinde bulunan bir firma ele alınmıştır. Araştırmaya konu olan firma, 4691 sayılı kanuna tabi ve MSUGT' ye göre muhasebe kayıtlarını yapan bir firmadır. TMS/TFRS Tam Set uygulama zorunluluğu bulunmayan ve de BOBİ FRS'yi kullanmayı tercih etmeyen bir firmadır. Firmanın mali müşavirinden elde edilen bilgiler, mizan ve mali tablolar doğrultusunda firmanın Ar-Ge faaliyetlerine ilişkin muhasebe kayıtları, 4691 sayılı TGBK' da belirtilen istisna ve teşvikler kapsamında MSUGT'ye göre oluşturulmuştur. Bu kayıtlar, TMS/TFRS Tam Set ve BOBİ FRS'ye uygun olarak da yapılmış; firmanın ilgili standartlara tâbi olması durumunda istisna ve teşvik kapsamında kayıtların nasıl şekilleneceği ortaya konulmuştur.

Ayrıca, 4691 sayılı kanun kapsamında “ kurumlar vergisi, katma değer vergisi, damga vergisi ve sosyal güvenlik pirim istisnalarının" gösterilmesi amac1 ile firmanın Kurumlar Vergisi beyannamesi alınmıştır. Buna ilişkin olarak da firmanın faaliyet konusu ile ilgili yaptığı satışlarından elde ettiği kazançlar üzerinden Kurumlar Vergisi Beyannamesindeki istisnalar gösterilmiştir.

Sonuç olarak söz konusu firmanın istisna kapsamındaki Ar-Ge faaliyetlerinin muhasebe kayıtlarında nasıl izlendiğini, dönem sonunda oluşan kâr ve zararı nasıl tespit ettiğini ve bunun kurumlar vergisi matrahını nasıl etkilediğini, Ar-Ge personeli ücret istisnasının ve diğer istisnai durumların nasıl muhasebeleştirildiğini göstermek amacıyla firmadan alınan 2018 yılı kesin mizan, gelir tablosu, dönem sonu bilançosu, ücret bordrosu ve kurumlar vergisi beyannamesi temin edilerek incelenmiştir.

\subsection{Hammadde Alımı Ve Kullanımına İlişkin Muhasebe İşlemleri}

\subsubsection{Hammadde Alımı}

Firmanın araştırma ve geliştirme konusu yaptığı 1 No.lu proje, gıda sektörüne hitap eden bir ürünün araştırılması ve geliştirilmesi ile ilgilidir. Üzerinde çalışılan proje için hammadde temin etmek amaciyla A firmasından \%18 KDV dâhil 236.000 TL, peşin olarak hammadde satın almıştır.

MSUGT' ye göre “işletmelerin üretiminde veya diğer faaliyetlerinde kullanmak üzere aldığ malzemeler" 150 İlk Madde ve Malzeme hesabında izlenmektedir. Bu sebeple firmanın satın 
almış olduğu hammadde 150 İlk Madde ve Malzeme hesabında ele alınmıştır. Bu konuda TMS/TFRS Tam Set ve BOBİ FRS uygulaması da aynı şekildedir. Bununla ilgili kayıt aşağıdaki gibidir.

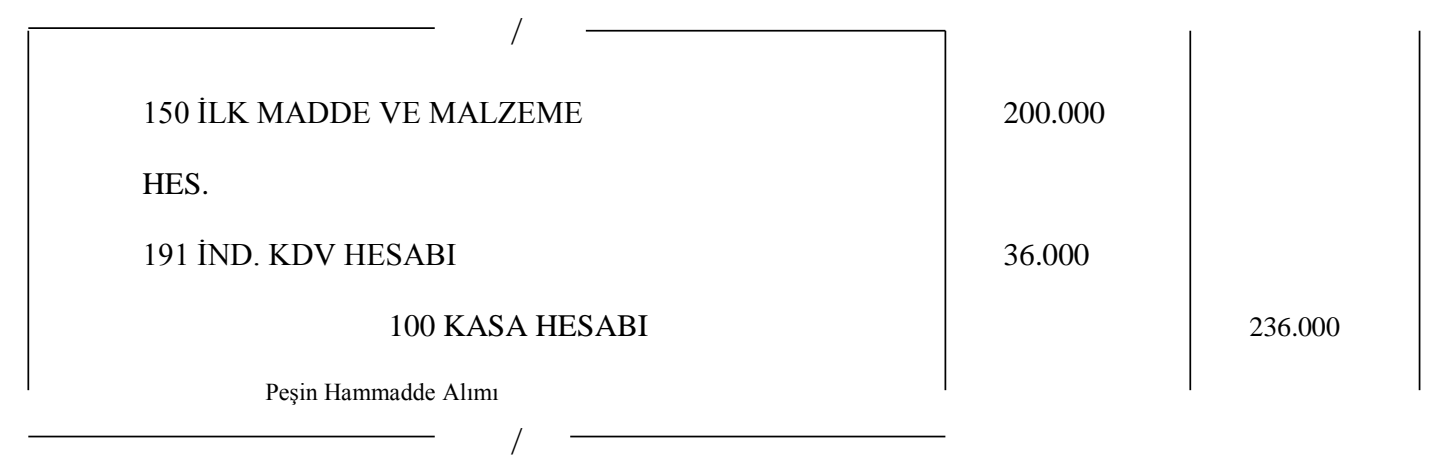

Şekil 1. Peşin hammadde alımı

Peşin hammadde alımıyla ilgili olarak uygulamalar arası farklılık yokken, vadeli hammadde alımında farklı durumlar söz konusu olmaktadır.

Yukarıda verilen örnek, vadeli alım şeklinde değiştirildiğinde ve ödeme tarihinin bir sonraki ay olduğu varsayıldığında kayıt işlemi değişecektir. Vade sonunda firmaya bu hammadde alışından dolayı faiz gideri doğacak ve bu gider MSUGT' ye göre yapılacak olan kaydı değiştirmezken; TMS/TFRS Tam Set'e göre yapılan kaydı farklılaştıracaktır. İlgili faiz gideri borçlanma maliyeti olarak ele alınacaktır.

Konuyla ilgili TMS-23 Borçlanma Maliyetleri Standard1 1. Maddesinde "bir özellikli varlığın elde edilmesinde, inşası veya üretimi ile doğrudan ilişkilendirilebilen borçlanma maliyetlerini bu varlığın maliyetinin bir parçası” olarak ele almıştır. Özellikli varlık ise standardın 5. maddesinde “ amaçlanan kullanıma veya satışa hazır duruma getirilebilmesi zorunlu olarak uzun bir süreyi gerektiren varlık” olarak tanımlanmıştır (TMS-23, 2015: 3).

Fakat söz konusu firmanın faaliyetinde bulunduğu varlığın kullanıma ve satışa hazır duruma gelebilmesi 1 yıldan daha kısa bir süreyi kapsadığından, bu varlık özellikli varlık kapsamında değerlendirilmeyecektir. Bu sebeple ilgili standardın 7. maddesine göre borçlanma maliyetleri, oluştukları dönemde etkin faiz yöntemine göre gider olarak kaydedilmektedir (TMS-23, 2015: 2). Borçlanma maliyetlerinin oluştukları dönemde gider olarak kaydedilmeleri, muhasebenin "Dönemsellik Kavramı” gereği, “780 Finansman Giderleri” ile mümkün olmaktadir.

Ancak BOBİ FRS ile TMS-23 Borçlanma Maliyeti Standardı, vade farkı noktasında ayrışmaktadır. BOBİ FRS'nin 14.9. maddesine göre “bir yıl veya daha kısa vadeli bir ödeme 
karşılığında satın alınan maddi olmayan duran varlıklar, vade farkı ayrıştırılmaksızın, ödenen veya ödenmesi beklenen nakit tutar üzerinden ölçülür.”

Dolayısıyla yukarıda ele alınan KDV dâhil 236.000 TL' lik hammadde alımının 1 ay vadeli ve $1.000 \mathrm{TL}$ vade farklı olarak yapıldığı varsayıldığında; vade farkı TMS/TFRS Tam Set' e göre 780 Finansman Giderleri hesabına kaydedilecektir.

MSUGT' ye ve BOBİ FRS' ye göre ise peşin hammadde alımı ile vadeli hammadde alımı kaydı arasında herhangi bir farklılık bulunmamaktadır. Ancak daha önce belirtildiği üzere vade 1 yılın üzerinde olduğunda BOBİ FRS de TMS/TFRS Tam Set ile aynı noktada birleşmektedir. 1 aylık vadeli alımda değișen kayıt aşağıda gösterildiği gibidir:

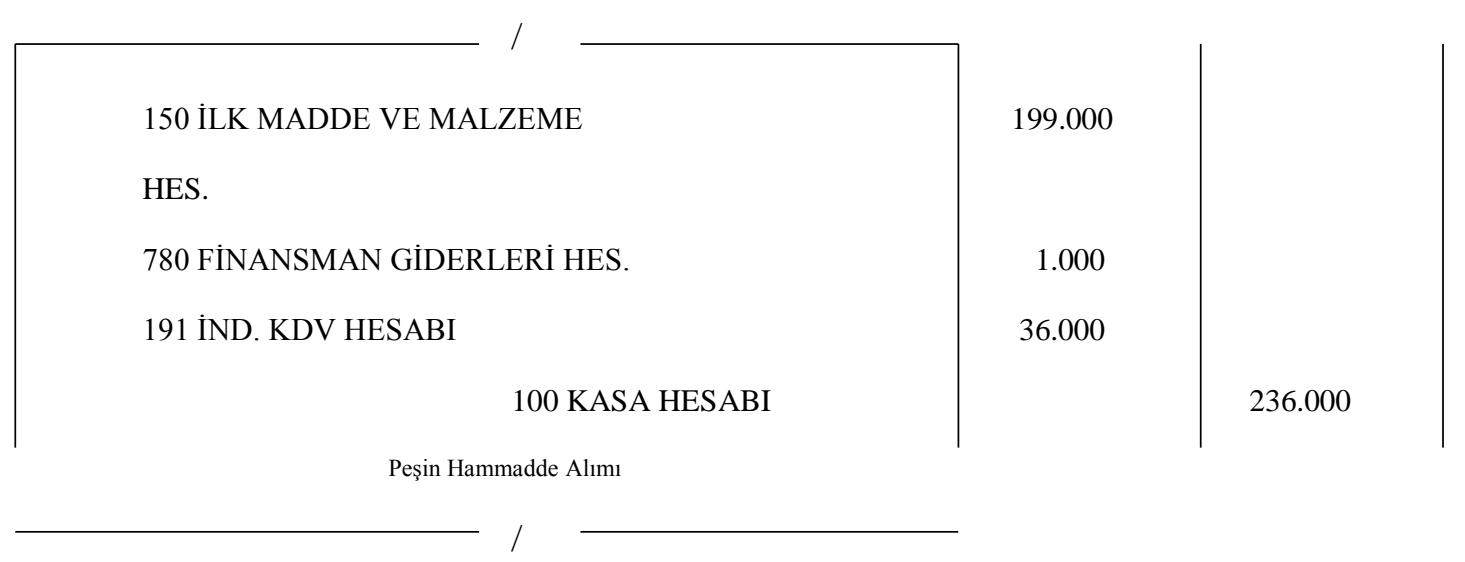

Şekil 2. Vadeli Hammadde Alımı

\subsubsection{Hammaddelerin Araştırma Faaliyetlerinde Kullanımı}

MSUGT Ar-Ge faaliyetleri için yapılan harcamaları muhasebeleştirirken araştırma safhası ve geliştirme safhası için, Ar-Ge işlemi gerçekleştirildiği anda bu faaliyet maliyetinin aktifleştirilebileceğine veya dönem gideri olarak muhasebeleştirilebileceğine olanak tanımıştır. Aktifleştirme tercih edildiğinde ilgili maliyet 263 Araştırma Ve Geliştirme Hesabı'nın borcuna, giderleştirme tercih edildiğinde ise 750 Araştırma Ve Geliştirme Gideri hesabının borcuna kaydedilmektedir. Çalışmaya konu firma da bu durumdan yola çıkarak ilgili gideri aktifleştirmiştir.

TMS-38 Maddi Olmayan Duran Varlıklar Standardında Ar-Ge faaliyetleri için yapılan harcamaların ne şekilde değerlendirileceğinden bahsedilirken standardın 54.-57. maddelerinde araştırma ve geliştirme safhası ile ilgili faaliyetlerin muhasebeleştirilmesine ilişkin esaslar ele alınmıştır. Standart, araştırma ve geliştirme giderlerini birbirinden ayırarak sadece geliştirme giderlerin aktifleştirilebileceğini belirtmektedir. Standardın 54. maddesine göre, “Araştırma 
(veya işletme içi bir projenin araştırma safhası) harcamaları gerçekleştiğinde gider olarak muhasebeleştirilir.” Bu doğrultuda incelenen firmanın 1 no.lu proje için aldığı hammaddelerin araştırma safhası için kullanılacak kısmı MSUGT' ye göre aktifleştirilirken TMS-38' e göre gider yazılmalıdır.

Ayrıca BOBİ FRS de 15. maddesinde "bir maddi olmayan duran varlığın kayda alınıp alınmayacağının değerlendirilmesinde, ilgili varlığın oluşum sürecini araştırma safhası ve geliştirme safhası olarak ikiye" ayırmış, 16. maddesinde ise araştırma safhasında yapılan harcamaların aktifleştirilmeyip, gerçekleştiği anda gider olarak kâr veya zarara yansıtılmasından bahsetmiştir. Bu noktada BOBİ FRS, TMS- 38 Maddi Olmayan Duran Varlık Standardı ile benzerlik göstermektedir.

Firma "150 İlk Madde ve Malzeme" hesabında ele aldığı hammaddelerin 120.000 TL tutarını Ar-Ge faaliyetinin araştırma safhasında kullanmıştır. Bununla ilgili kayıt aşağıdaki gibidir 
Kendir, E., Aslantaş Ateș, B.

Tablo 1. Hammaddelerin Kullanımına İlişkin Yevmiye Kayıtları

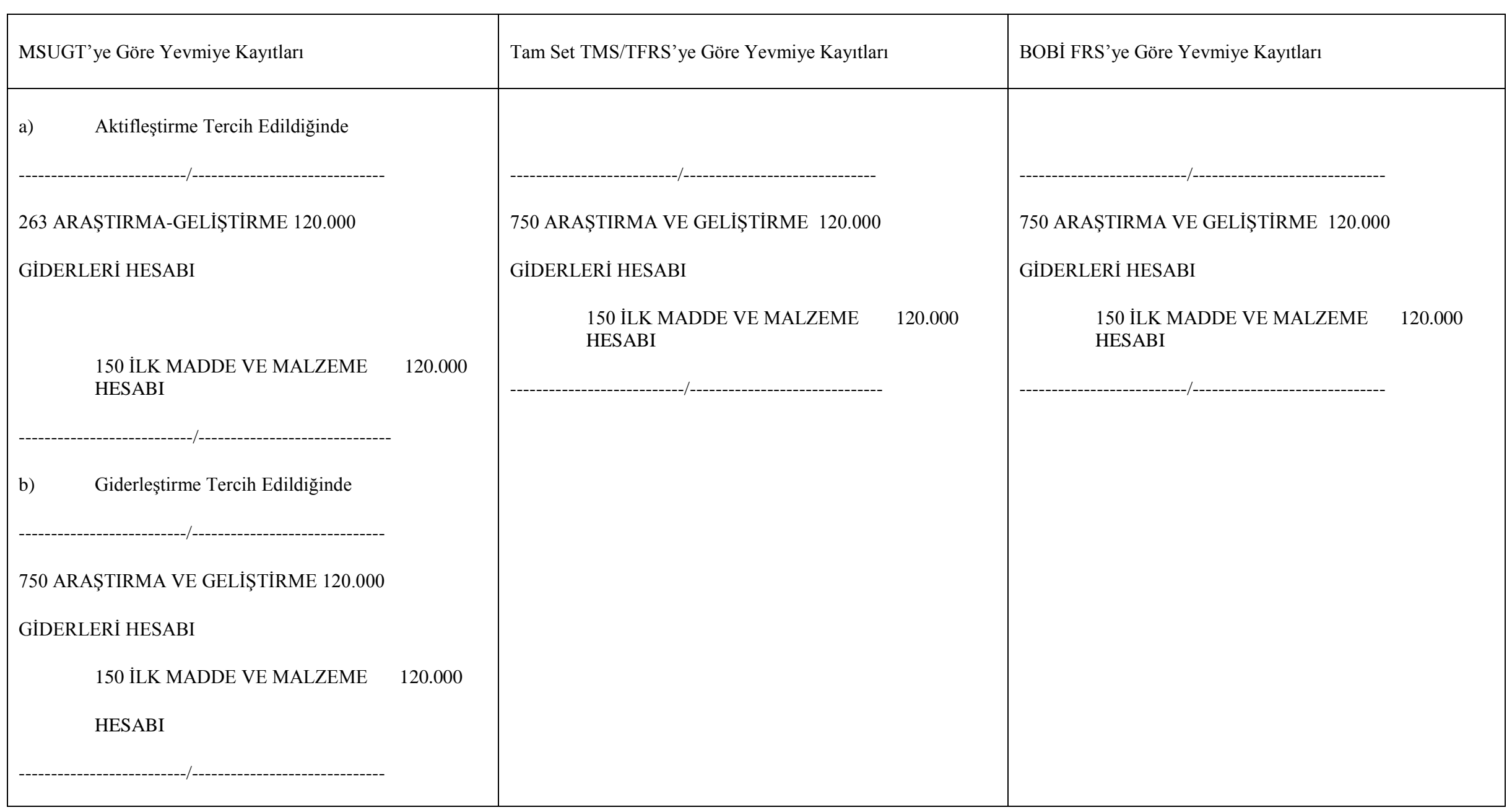




\subsubsection{Hammaddelerin Geliştirme Safhasında Kullanımı}

MSUGT işletmelerin geliştirme safhasında Ar-Ge faaliyeti ile ilgili yapılan muhasebe kayıtlarını başta benimsemiş oldukları yaklaşıma göre devam etmelerine olanak tanımıştır. $\mathrm{Bu}$ sebeple MSUGT'yi benimseyen işletmelerde Araştırma ve Geliştirme süreçlerinin ayrımı çok büyük bir önem taşımaz. Yani MSUGT açısından araştırma ile geliştirme sürecinin muhasebe kayıtlarında herhangi bir farkı yoktur.

Muhasebeleştirme işlemi TMS/TFRS Tam Set açısından değerlendirildiğinde yukarıda da bahsedildiği üzere, araştırma ile geliştirme safhalarının birbirinden ayrı ele alındığı görülmektedir. TMS-38 Maddi Olmayan Duran Varlık Standard1 58. Maddesinde geliştirme safhasında kullanılmak üzere hammadde alımıyla ilgili açıklama yapılmışır. Bu maddeye göre; "işletme içi yaratılan bir projenin geliştirme safhasında, bazı durumlarda işletmenin, bir maddi olmayan duran varllğı tespit edebileceğini ve ilgili varllğın gelecekte muhtemel ekonomik yararlar yaratacağını" gösterebildiğini söylemiş̧tir. Bunun sebebi ise, "geliştirme safhasının araştırma safhasından daha ileri bir safha" olarak göstermesidir.

Muhasebeleştirme işlemi BOBİ FRS açısından değerlendirildiğinde ise standardın 14.17 nolu maddesinde belirtilen şartların tamamının karşılanması halinde geliştirme safhasında yapılan harcamaların maddi olmayan duran varlık olarak aktifleştirilebileceğinden bahsetmiş̧tir. Bu maddenin şartları;

“a) Maddi olmayan duran varlığın kullanıma veya satışa hazır hale gelebilmesi için tamamlanmasının teknik olarak mümkün olması,

b) İşletmenin maddi olmayan duran varlığı tamamlama ve bu varllğı kullanma veya satma niyetinin bulunması,

c) İşletmenin maddi olmayan duran varlığı kullanma veya satma imkânının bulunması,

ç) Maddi olmayan duran varlığın muhtemel gelecek ekonomik faydayı nasıl sağlayacağının belirli olması. Ayrıca, maddi olmayan duran varlığın veya ürününün bir piyasasının olması ya da işletme bünyesinde kullanılmaya elverişli olması,

d) Geliştirme safhasını tamamlamak ve maddi olmayan duran varlığı kullanmak veya satmak için yeterli teknik, mali ve diğer kaynakların mevcut olması,

e) Geliştirme sürecinde maddi olmayan duran varlıkla ilgili yapılan harcamaların 
Standart 14.18 nolu maddesinde "yukarıda belirtilen şartların sağlandığı tarihten itibaren katlanılan harcamaların işletmede oluşturulan maddi olmayan duran varlığın maliyetini oluşturacağını” belirtmiştir.

Uygulamaya konu olan firma geliştirme safhası için, daha önce satın almış olduğu hammaddelerin kalan 80.000 TL'lik kısmını geliştirme safhasında kullanmıştır. Aşağıda MSUGT, TMS/TFRS Tam Set ve BOBİ FRS'ye göre geliştirme safhasındaki hammadde kullanımlarına ilişkin muhasebe kayıtları yapılmıştır. 
MAKÜ-BIFD 3(2), 192-221, 2020

Tablo 2. Geliştirme safhasında hammaddelerin kullanımına ilişkin yevmiye kayıtları

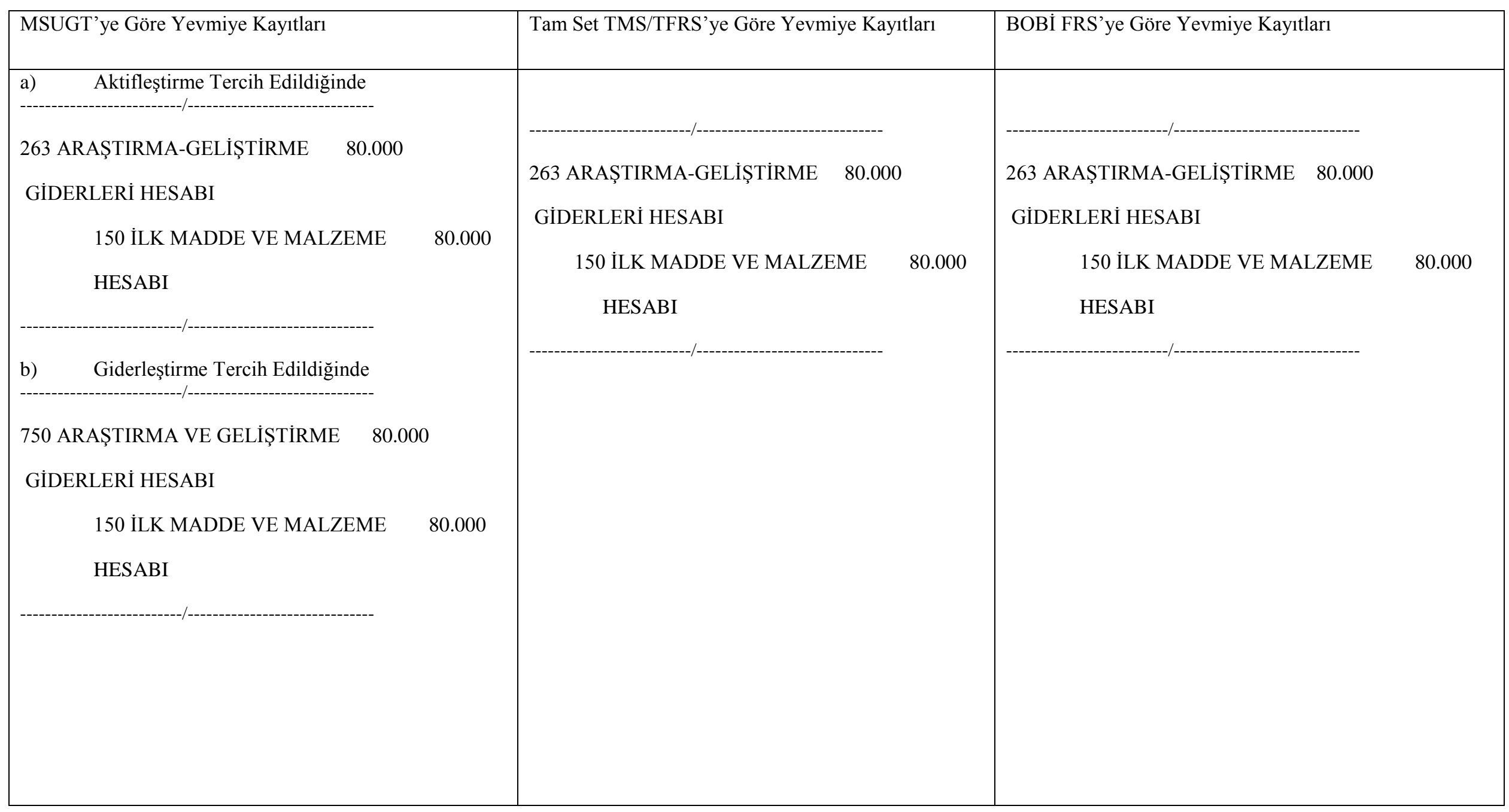




\subsection{Personel Ücretlerine İlişkin Muhasebe İşlemleri}

Firmadan alınan bilgiler doğrultusunda 2018 dönemine ait firmada çalışan Ar-Ge personellerinin ücretiyle ilgili düzenlenen Ocak, Şubat ve Mart aylarına ait ücret bordrosu ve tahakkuk bilgilerine ulaşılarak söz konusu tahakkuk bilgilerine ilişsin muhasebe kayıtları yapılmıştır.

Çalışmada ele alınan firmada 3 personel çalışmakta olup bunlardan ikisi Ar-Ge faaliyetinde çalışmaktadır. Firmada Ar-Ge faaliyetinde çalışan 2 personelin brüt ücretleri 20.753,28 TL'dir. Bu tutar üzerinden 4.254,42 TL İşveren Sigorta Pay1, 415,08 TL İşveren İşsizlik Sigortası, 35,70 TL SGK Primi Damga Vergisi hesaplanarak ilgili hesabının toplam tutar1 25.458,47 TL'dir.

Personele ödenecek net ücretler 335 Personele Borçlar hesabında ele alınıp bu tutar 17.640,25 TL olarak hesaplanmıştır. İstisna kapsamına dâhil edilen gelir ve damga vergisi 360 Ödenecek Vergi ve Fonlar hesabında 2.803,55 TL olarak hesaplanmış ve bu tutar 4691 sayılı kanun kapsamında muaf tutulmuştur. İşçi pirimi sigortaları 361 Ödenecek Sosyal Güvenlik Kesintileri hesabında ele alınmış, \%5 oranında 5510 Sayılı Sosyal Sigortalar ve Genel Sağlık Sigortası Kanunu kapsamında sabit indirim olarak 1.037,66 TL, \% 7,75 oranında 4691 Say1lı Kanun kapsamında 1.608,38 TL sigorta indirimi hesaplanarak firma toplamda 2.646,06 TL'lik teşvik geliri almıştır.

Ücretin yevmiye kayıtları açısından üzerinde durulması gereken başka bir durum ise, firmada çalışan personelin damga vergisi ve sigorta istisnasından faydalanıp faydalanmadı̆̆ıdır. Bununla ilgili ücret bordrosunda fazla mesai ücreti gösterilmemesi, kayıtlarda bu ayrıma tabi tutulmaması, çalışanların mesailerinin ne kadarını Ar-Ge faaliyetinde kullandığını belirsiz kılmaktadır. Bu durumda firma 4691 sayılı Kanun kapsamındaki sigorta desteğini, çalışan personelinin dönem gideri olarak kaydettiği tutar olan sigorta giderlerinden, gelir hesapları kullanarak mahsup etmektedir.

Yukarıda bahsedilen gelir vergisi, damga vergisi ve SSK işveren pirimi desteği 4691 sayılı TGBK kapsamında tek tek ele alınmış olup MSUGT' de bu istisnaların nasıl kaydedilmesi gerektiği açıklanmıştır. MSUGT'ye göre istisnalar yukarıdaki kayıtlar doğrultusundadır; "sigorta pirim desteği işletmenin faaliyet hasılatındaki düşüklüğü veya faaliyet zararını gidermek için, sermaye katkısı niteliğinde olmayan, mali yardımlar, devletin bazı malları vergi, resim, harç vb. yükümlülüklerden istisna etmesi yoluyla yaptığı yardımlar gibi hasılat kalemleri” MSUGT’ ye göre 602 Diğer Gelirler hesabında izlenmelidir. 
Ayrıca TMS-20 Devlet Teşviklerinin Muhasebeleştirilmesi ve Devlet Yardımlarının Açıklanması Standardı (TMS-20, 2005) 3. maddesinde devlet teşviklerini “İşletmenin faaliyet konuları ile ilgili belirli koşulların geçmişte veya gelecekte yerine getirilmesi karşılı̆̆ında işletmeye kaynak transferi şeklindeki devlet yardımlarıdır" olarak tanımlamış olup (TMS-20 , 2005: 1) 29. maddesinde bu teşviklerin muhasebeleştirilmesiyle ilgili bilgi vermiştir. $\mathrm{Bu}$ maddeye (TMS-20 , 2005: 3) göre “Gelire ilişkin teşvikler kâr veya zararın bir parçası olarak ayrı bir şekilde veya "Diğer Gelirler" genel başlı̆̆ı altında, alternatif olarak da ilgili giderlerden düşülerek gösterilir”.

MSUGT’ ye göre ve TMS-20 Devlet Teşviklerinin Muhasebeleştirilmesi ve Devlet Yardımlarının Açıklanması Standardına göre istisna pirim desteği kaydı aşağıdaki kayıtla uyumludur.

BOBİ FRS Devlet Teşviklerini 16. Bölümün 2. Maddesinde "faaliyet konularıyla ilgili belirli şartların karşılanması durumunda, kaynak transferi şeklinde işletmelere yapılan devlet yardımları" olarak tanımlamış 4. Maddesinde ise "parasal veya parasal olmayan olarak ayırmayıp devlet yardımlarını kurumlar vergisi, yatırım indirimleri, hızlandırılmış amortisman uygulamaları ve indirimli vergi oranları" olarak göstermiştir. Standarda göre "işletmenin gelecekte herhangi bir performans şartını yerine getirmesini gerektirmeyen ya da performans şartını önceden yerine getirdiği teşvikler, alındıkları anda kâr veya zarara yansıtılır” (md. 7). $\mathrm{Bu}$ firmanın aldığı teşvik performans şartına bağlı olmadığı için BOBİ FRS' ye göre sigorta pirim desteği olan 2.646,06 TL' y1 649 nolu Diğer Olağan Gelir ve Kârlar hesabında izlemek gerekir. Ar-Ge personeline ilişkin ücretlerin muhasebeleştirilmesi Araştırma ve Geliştirme aşamalarında farklılıklar gösterebilmektedir. Buna göre MSUGT açısından başta işletme tarafından belirlenen yaklaşım (aktifleştirme veya giderleştirme) kapsamında devam edecek olmasına rağmen TMS/TFRS Tam Set ve BOBİ FRS'de değişiklikler olabilmektedir. Bu nedenle aşağıda araştırma ve geliştirme safhalarına göre muhasebe kayıtlarına yer verilmiştir. 
Kendir, E., Aslantaş Ateş, B.

Tablo 3. Araştırma safhasında personel giderlerine ilişkin yevmiye kayıtları

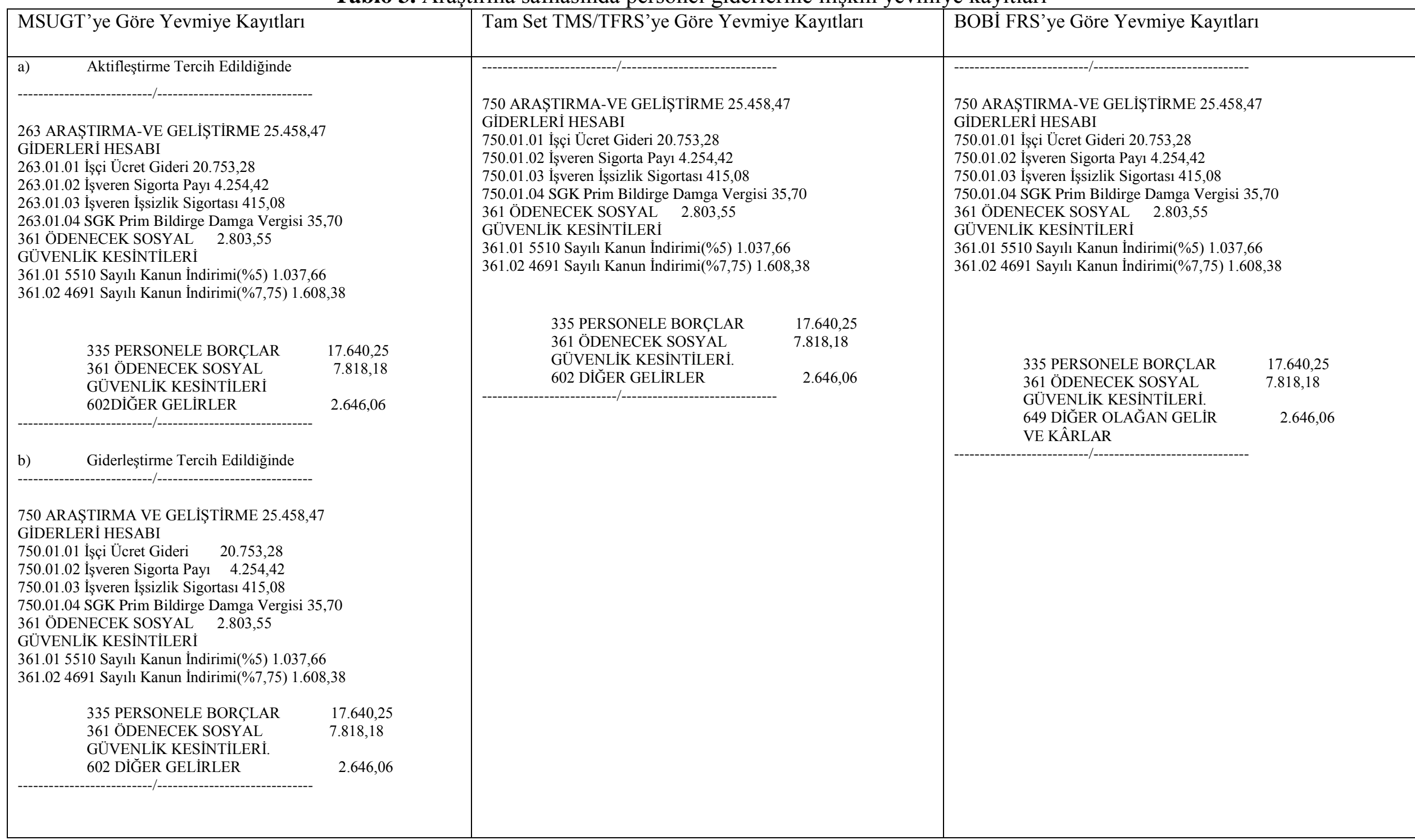




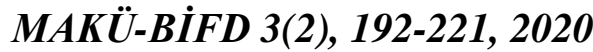

Tablo 4. Geliştirme safhasında personel giderlerine ilişkin yevmiye kayıtları

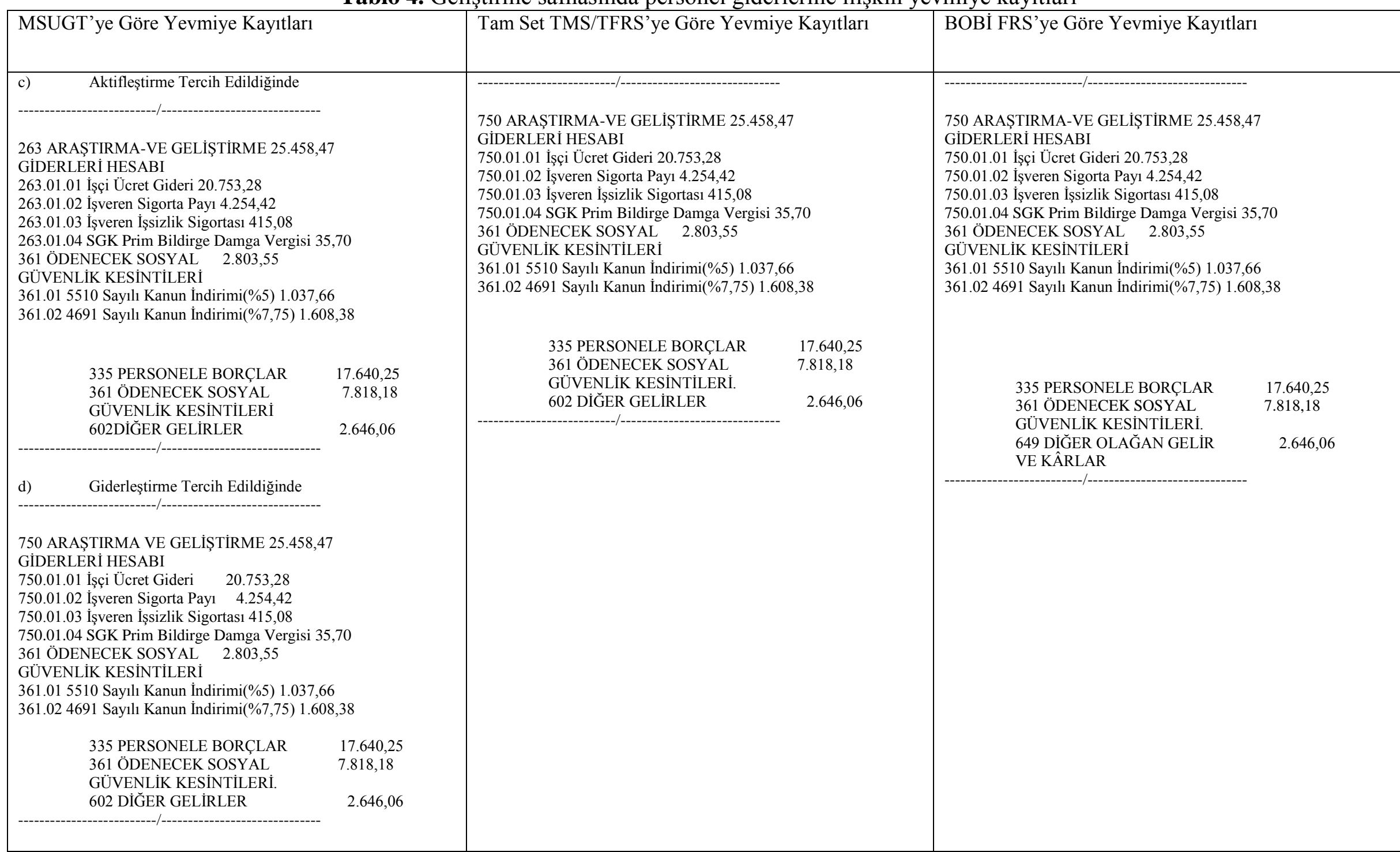




\subsection{Satışlara İlişkin Muhasebe İşlemleri}

Firmanın 1 no.lu proje kapsamında ürettiği mamul yurtiçine ve yurtdışına peşin satılmıştır. Yurtiçi satışlarının 185.272,00 TL'lik kısmını 600 Yurtiçi Satışlar hesabında ve yurtdışı satışlarının 205.752,00 TL'lik kısmını ise 601 Yurtdışı Satışlar hesabında izlemiştir. Firmanın çalışmanın ikinci bölümümde bahsedilen 4691 sayılı kanun kapsamındaki KDV istisnasından faydalanmasından dolayı yurtiçi ve yurtdışı satışlarından KDV hesaplanmamıştır. Büyük defter kayıtları incelendiğinde işletmenin dönem sonunda 185.272,00 TL'si yurtiçi, 205.752,00 TL'si yurtdışı olmak üzere toplam satışları 391.024,00 TL'dir.

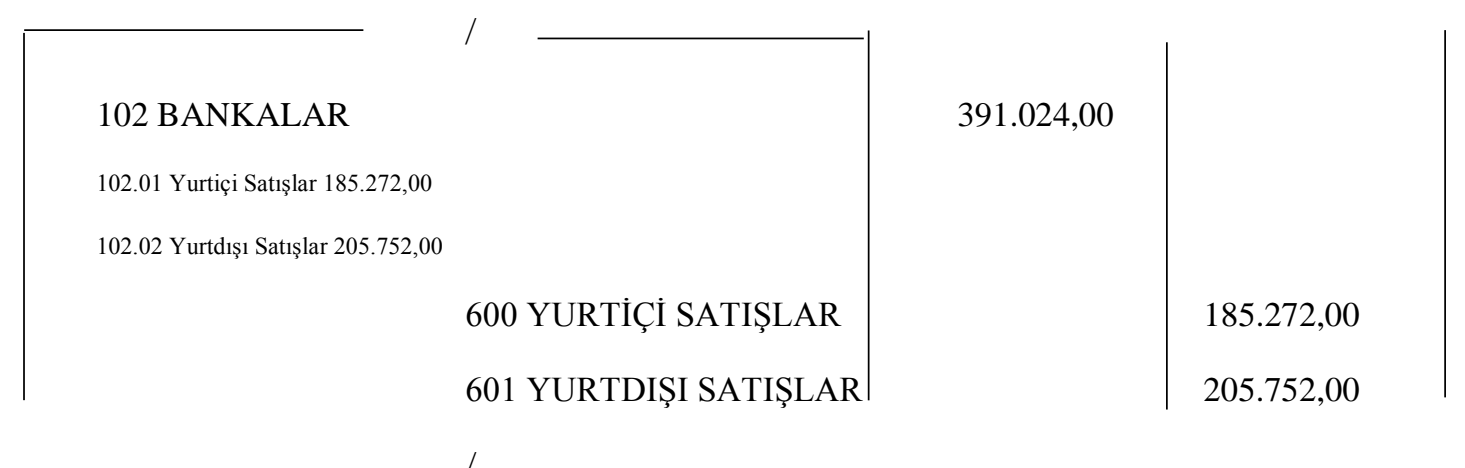

Şekil 3. Satışların kaydı

TMS/TFRS Tam Set ve BOBİ FRS'ye göre satış kaydı farklılık göstermemektedir. Dolayısıyla kayıt tekrarlanmamıştır.

\subsection{Kurumlar Vergisi}

5520 Sayılı Kurumlar Vergisi Kanuna (5520 Say1lı Kurumlar Vergisi Kanunu, 2006) göre söz konusu firma için 2018 yılı Kurumlar Vergisi matrahına aşağıdaki şekilde ulaşılması gerekmektedir.

"Ticari Bilanço Kârı(A)

“Kanunen Kabul Edilmeyen Giderler(B)

“Zarar Olsa Dahi İndirilecek İstisna ve İndirimler(C)

“4691 Kazanç İstisnası

“Kâr ve İlaveler Toplamı(A+B)

“Cari Yıla Ait Zarar, İstisna ve İndirimler Toplamı(C)
68.035,07 TL"

$$
0,00 \text { TL" }
$$

68.035,07 TL"

(68.035,07 TL)"

68.035,07 TL"

$68.035,07 \mathrm{TL} "$ 
"Kâr(D)=[(A+B)-C]

$0,00 \mathrm{TL} "$

“Dönem Safi Kurum Kazancı (Mali Kâr)(D)

$0,00 \mathrm{TL} "$

"Kurumlar Vergisi Matrahı(D)

$0,00 \mathrm{TL} "$

"Hesaplanan Kurumlar Vergisi $(\mathrm{E})=(\mathrm{D} * \% 22)$

$(0,00) \mathrm{TL} "$

İşletmelerin kurumlar vergisi matrahının hesaplanabilmesi için safi kazancın hesaplanması gerekir. Bu sebeple ele alınan firma için 2018 yılı vergi öncesi bilanço kârı hesaplanmış olup bu tutar 68.035,07 TL'dir. Söz konusu kâr için firma 2018 yılı faaliyeti sonucu elde etmiş olduğu ticari bilanço kârı olan 68.035,07 TL'yi kurumlar vergisi beyannamesinin “ indirilecek istisna ve indirimler " bölümünde Ar-Ge istisna kısmına yazılarak firma kurumlar vergisinden muaf olarak beyannamesini 25 Nisan 2019 tarihinde vermiştir. Firmanın 4691 Sayılı TGBK kapsamında sağlanan kurumlar vergisi istisnasından faydalanmamış olması durumunda ödeyeceği kurumlar vergisi 14.967,72 TL tutarına olacaktı. Kurumlar vergisi firma 4691 Sayılı TGBK kapsamında sağlanan istisna ve teşviklerden faydalandığından dolayı beyannamede 0,00 TL tutarında gösterilmektedir Fakat firma her ne kadar kurumlar vergisinden istisna olsa dâhi MSUGT uyarınca ticari bilanço kârının \%22 oranında 14.967,72 TL tutarında vergi karşılığı ayırmak zorundadır. Bunun sonucunda oluşan firmanın bilançosunda belirtilen vergi sonrası net kârı 53.067,35 TL olarak hesaplandığı görülmüştür.

\subsection{Amortisman Giderlerinin Muhasebeleştirilmesi}

Firma tamamen Ar-Ge faaliyeti gösterdiğinden dolayı firmaya alınan ortak varlıklar da Ar-Ge faaliyeti olarak değerlendirilip 268 Birikmiş Amortismanlar hesaplarında kayıtları yapılmıştır. MSUGT' ye göre bu hesap "Maddi olmayan duran varlık bedellerinin, kullanılabilecekleri süre içerisinde yok edilebilmesini sağlamak amacıyla kullanılan hesaptır” şeklinde tanımlanıp işleyişi ise “ Ayrılan amortismanlar, ilgili gider hesapları karşılığında bu hesaba alacak; kullanım hakkı sona erenler ya da elden çıkarılanlar hesaba borç, ilgili varlık hesabına alacak kaydedilir” şeklinde açıklanmaktadır (26.12.1992 tarihli ve 21447 Mükerrer Sayılı Resmi Gazete'de yayımlanan 1 Sıra No.lu Muhasebe Sistemi Uygulama Genel Tebliği).

TMS-38 Maddi Olmayan Duran Varlık Standardının 89. maddesine göre "bir maddi olmayan duran varlığın muhasebeleştirilmesinde yararlı ömrü dikkate almaktadır. Sınırlı bir yararlı ömre sahip bir maddi olmayan duran varlık itfaya tabi iken, sınırsız yararlı ömürlü bir maddi olmayan duran varlık itfaya tabi olmamaktadır" (TMS-38: 16). 
BOBİ FRS 14.22 de "faydalı ömrü sınırlı olan maddi olmayan duran varlıklar için itfa payı ayrılması zorunlu" tutmuştur. İtfaya tâbi tutar BOBİ FRS 14.23'te açıklanmış buna göre "maddi olmayan duran varlı̆̆ın maliyet bedelinden kalıntı değerin indirilmesi suretiyle" belirlenmektedir. 14.25 'e göre ise "itfa işlemine, varlık kullanıma hazır olduğunda başlanır" ilgili “varlıklar için kullanılan gün esasına göre kıst amortisman hesaplanır”.

TMS-38 ile BOBİ FRS'de faydalı ömrün belirlenmesinde farklılık görülmektedir. TMS38' e göre faydalı ömrü belli olmayan bir varlık için değer düşüklüğü testi uygulanmaktadır. Fakat BOBİ FRS'nin 14.33. maddesine göre ise bu gibi durumdaki varlı̆̆ın itfası "5 yıldan az 10 yıldan çok" olmayacak şekilde ilgili işletme tarafindan belirlenen süre içerisinde itfa edilebilecektir.

Çalışmada ele alınan firma için varlığın 5 yıl içerisinde itfa edilmesine karar verilmiştir. MSUGT, TMS/TFRS Tam Set ve BOBİ FRS' ye göre maddi olmayan duran varlığın büyük defter kayıtları incelendiğinde 268 no.lu hesabın alacak kalanının 67.638,148 TL olduğu görülmektedir. Firmanın 2018 yılı dönem sonu maddi olmayan duran varlığın amortisman kaydı MSUGT, TMS/TFRS Tam Set ve BOBİ FRS açısından farklı ve aşağıdaki şekilde olmaktadır. Amortisman rakamlarındaki farklılık, amortisman hesaplanan varlığın defter değerinin MSUGT ve standartlarda üst kısımlarda anlatıldığı şekilde farklı hesaplanmasındandır. 
Tablo 5. Maddi olmayan duran varlıkların amortismanının muhasebeleştirilmesine ilişkin yevmiye kayıt

\begin{tabular}{|c|c|c|}
\hline MSUGT'ye Göre Yevmiye Kayıtları & Tam Set TMS/TFRS'ye Göre Yevmiye Kayıtları & BOBİ FRS'ye Göre Yevmiye Kayıtları \\
\hline $\begin{array}{l}\text { 750 ARAŞTIRMA VE GELIŞTIRME 67.638,148 } \\
\text { GİDERLERİ HESABI }\end{array}$ & $\begin{array}{l}\text { 750 ARAŞTIRMA VE GELIŞTIRME } \quad 67.238,148 \\
\text { GIDERLERİ HESABI }\end{array}$ & $\begin{array}{l}\text { 750 ARAŞTIRMA VE GELIŞTIRME } \quad \text { 67.638,148 } \\
\text { GİDERLERİ HESABI }\end{array}$ \\
\hline $\begin{array}{l}\text { 268 BİRIKMIŞ } 67.238,148 \\
\text { AMORTISMANLAR } \\
1 \text { Nolu Proje İçin Giderlerin Amortismanının } \\
\text { Giderleştirilmesi }\end{array}$ & $\begin{array}{l}\text { 268 BİRİKMIŞ } \quad 67.238,148 \\
\text { AMORTİSMANLAR } \\
\text { 1 Nolu Proje İçin Giderlerin Amortismanının } \\
\text { Giderleştirilmesi }\end{array}$ & $\begin{array}{l}\text { 268 BİRIKMiş̧ 67.238,148 } \\
\text { AMORTISMANLAR } \\
1 \text { Nolu Proje İçin Giderlerin Amortismanının } \\
\text { Giderleştirilmesi }\end{array}$ \\
\hline
\end{tabular}


Kendir, E., Aslantaş Ateş, B.

Firma Ar-Ge faaliyetinde kullanılmak üzere almış olduğu maddi duran varlıkların amortisman kaydını 257 Birikmiş Amortismanlar hesabında muhasebeleştirmiştir. MSUGT' ye göre bu hesap "Maddi duran varlık bedellerinin, kullanılabilecekleri süre içerisinde hesaben yok edilebilmesini sağlamak amacıyla kullanılan pasif karakterli hesaptır. Ayrılan amortismanlar ilgili gider hesapları karşılığında bu hesaba alacak kaydedilir, satılan, devredilen, kullanma yeteneğini kaybedenler ise birikmiş amortismanlar hesabına borç kaydedilir, ilgili varlık hesabına da alacak kaydedilir".

TMS-16 Maddi Duran Varlık Standardı amortismana tabi tutarı "bir varlığın maliyetinden veya maliyet yerine geçen diğer tutarlardan kalıntı değerin düşülmesiyle bulunan tutar" olarak amortismanı ise; "bir varlı̆̆ın amortismana tabi tutarının, yararlı ömür süresince sistematik olarak dağıtılması" şeklinde tanımlamıştır. Dolayısıyla işletmeler ilgili standardın madde hükümlerine göre ellerinde bulundurdukları maddi duran varlıkları amortismana tabi tutmaktadırlar. Buna göre "bir varlığın amortismana tabi tutarı yararlı ömrü boyunca sistematik olarak dağıtılır” (md.50).

Standart madde 57 de "bir varlığın yararlı ömrünü işletmenin varlıktan beklediği faydaya göre” belirlediğini söylemiştir. "İşletmenin varlık yönetimi politikası, varlıkların belirli bir süre ya da gelecekteki ekonomik yararlarının belirli oranda tüketilmesinden sonra elden çıkarılmasını gerektirebilir. Bu nedenle, bir varlığın yararlı ömrü ekonomik hizmet süresinden kısa olabilir ve yararlı ömrünün tahmini, işletmenin benzer varlıklara ilişkin tecrübelerine dayanan bir takdir meselesidir" (md.57).

Standart ayrıca madde 62 de "işletmeler için bir varlığın amortismana tabi tutarının yararlı ömrü boyunca sistematik olarak dağıtabilmeleri için çeşitli amortisman yöntemlerini”" kullanabileceğinden bahsetmiştir. "Bu yöntemler doğrusal amortisman yöntemi, azalan bakiyeler yöntemi, ve üretim miktarı yöntemlerini içerir. Doğrusal amortisman yönteminde, varlığın kalıntı değeri değişmediği sürece, amortisman gideri yararlı ömrü boyunca sabittir. Azalan bakiyeler yönteminde, amortisman gideri yararlı ömür boyunca azalmaktadır. Üretim miktarı yönteminde beklenen kullanım ya da üretim miktarı üzerinden amortisman ayrılmaktadır. İşletme, varlığın gelecekteki ekonomik yararlarının beklenen tüketim biçimini en çok yansıtan yöntemi seçmektedirler. Seçilen yöntem gelecekteki ekonomik yararların beklenen tüketim biçiminde bir değişiklik olmadıkça dönemden döneme tutarlı olarak uygulanmaktadır" (md. 62). 
Ayrıca BOBİ FRS Maddi Duran Varlık için 12. Bölümün 21. Maddesinde amortisman ayrılmasını zorunlu tutmuştur. Buna göre amortismana tâbi tutar, "maddi duran varlığın maliyet bedelinden kalıntı değerinin indirilmesiyle” belirlenmektedir (md. 24). BOBİ FRS de yukarıda ele alınan TMS-16 nın temel noktalarını ele alarak maddelerini ifade etmiştir. Maddi duran varlığın amortismana tâbi tutarı 25. Maddeye göre faydalı ömrü süresince sistematik bir şekilde dağıtılmaktadır. Standarda göre faydalı ömür, "bir varlığın işletme tarafından beklenen kullanım süresini ya da işletme tarafindan ilgili varlıktan elde edilmesi beklenen üretim veya kullanım miktarını ifade etmektedir". "Faydalı ömür işletme tarafından gerçekçi tahminlere dayanılarak belirlenmektedir" (BOBİ FRS, 2017: 86). "Maddi duran varlığın amortisman işlemine, varlığın kullanıma hazır olduğu anda başlanır ve varlığın finansal tablo dışı bırakılmasıyla son verilir. Dolayısıyla dönem içerisinde kullanıma alınan varlıklar için kullanılan gün esasına göre kıst amortisman hesaplanır" (md. 26).

Firma araştırma safhasında püskürtmeli kurutucu almış olup bu makine veya teçhizatın 42.000 TL'lik amortisman itfa payını MSUGT'ye göre muhasebeleştirmiştir. Yukarıdaki maddeler de göz önünde bulundurulduğunda TMS/TFRS Tam Set ve BOBİ FRS' na göre yapılması gereken kayıt aşağıdaki şekilde olmaktadır. 
Kendir, E., Aslantaş Ateş, B.

Tablo 6. Maddi duran varlıkların amortismanlarına ilişkin yevmiye kayıtları

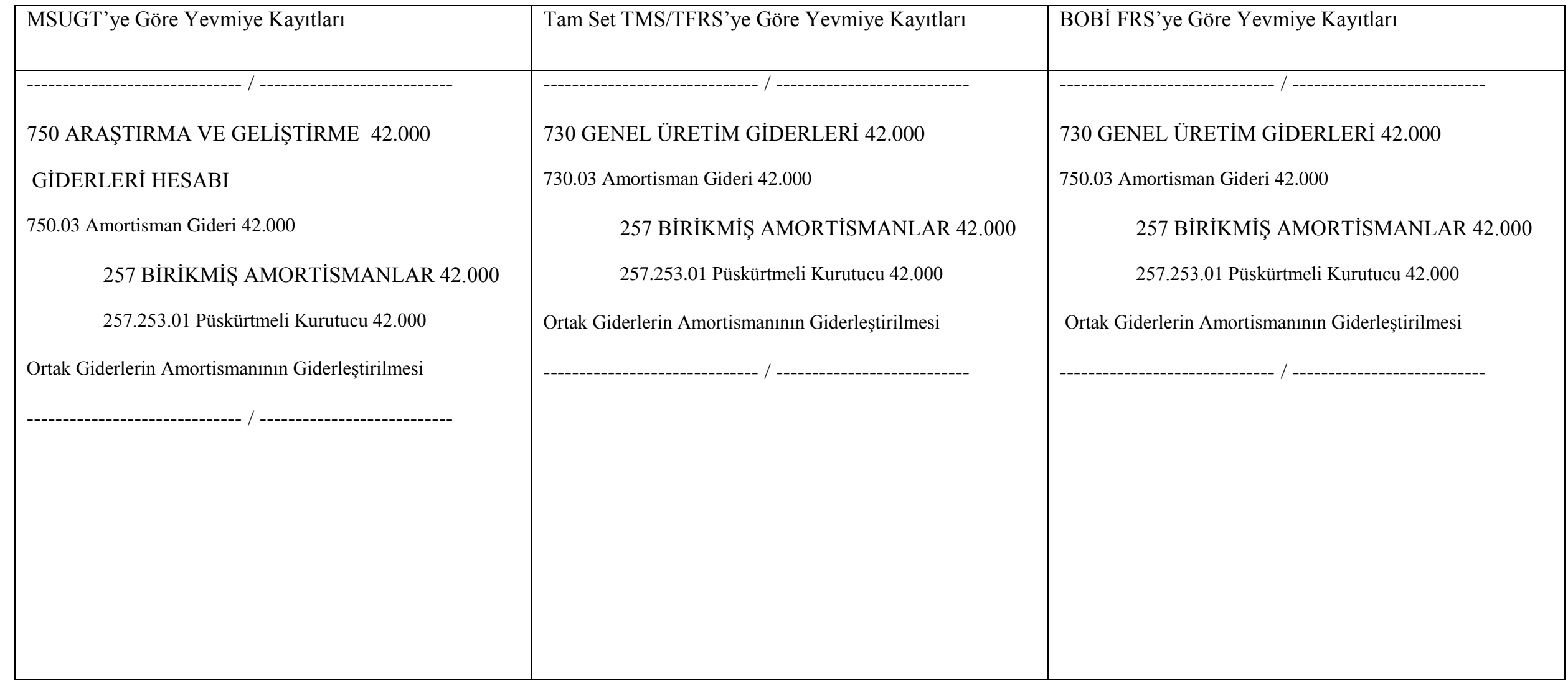




\subsection{Bağış ve Desteklerin Muhasebeleştirilmesi}

Söz konusu firma 2018 yılında Ar-Ge faaliyetleri kapsamında 150.000 TL KOSGEB desteği almış ve bu geliri MSUGT kapsamında 602 numaralı Diğer Gelirler hesabında muhasebeleştirmiştir.

Çalışmanın işçi ücretlerine ilişkin muhasebe kaydı kısmında belirtildiği üzere TMS 20 Devlet Teşviklerinin Muhasebeleştirilmesi ve Devlet Yardımlarının Açıklanması Standardında gelire ilişkin teşviklerin “diğer gelirler” başlığı altında gösterilebileceğinden bahsedildiği açıklanmıştı. Bu durumda yukarıdaki 150.000 TL' lık KOSGEB desteği 602 numaralı Diğer Gelirler hesabında izlenmelidir.

Yine yukarıda işçiliğin muhasebe kaydı kısmında açıklandığı gibi buradaki 150.000 TL' lık desteğin de BOBİ FRS' na göre 649 Diğer Olağan gelir ve Kârlar hesabında izlenmesi uygundur. MSUGT, TMS/TFRS Tam Set ve BOBİ FRS'ye göre yapılması gereken kayıt aşağıda verilmiştir.

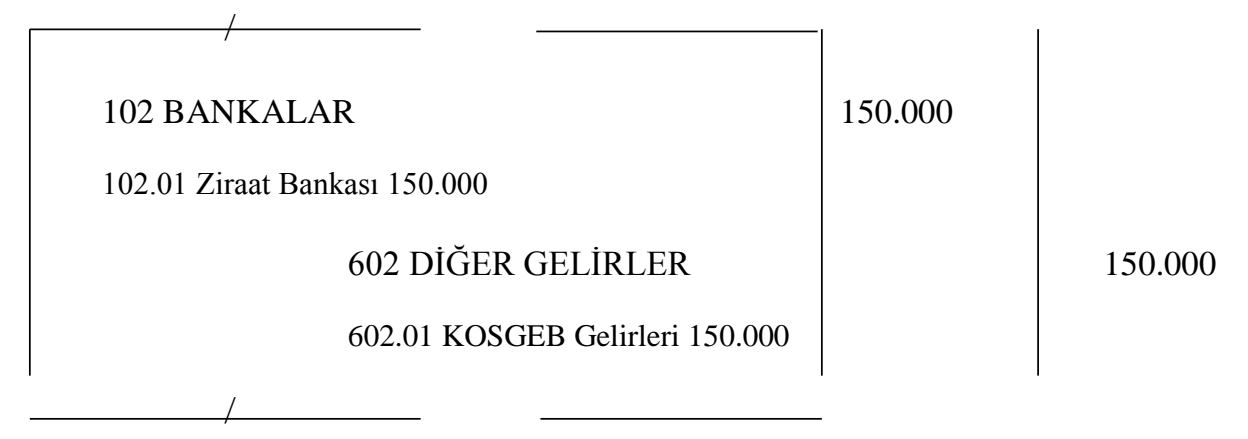

Şekil 4. Bağış ve desteklerin muhasebeleştirilmesi

\subsection{Proje Sonuç Değerlendirilmesi}

Söz konusu firma Ar-Ge faaliyeti süresince gerek kullanmış olduğu sabit kıymetler gerekse yönetimsel faaliyetler için yapmış olduğu giderlerin tamamı firma tamamen Ar-Ge firması olduğu için Ar-Ge faaliyetleri kapsamında değerlendirilmiş olup muhasebe kayıtları da bu doğrultuda yapılmıştır. Firmanın temin etmiş olduğu sabit değer ve gider kalemleri içerisinde kullanılmayan sabit değer ve diğer gider kalemleri firma bilançosunun aktif kısmında yer almaktadır. Firma projesini tamamlamış olup 513.419,97 TL değerinde Ar-Ge faaliyet kıymetinin 102.683,99 TL'lik kısmını kullanmış kalan kısmını da daha sonra gerçekleştireceği proje faaliyetlerinde kullanmak üzere 263 Araştırma ve Geliştirme Giderleri hesabının aktifinde bekletmiştir.

\section{SONUÇ}

İnovasyon yaratıcı bir fikri, katma değer yaratabilir ve pazarlanabilir bir ürün seviyesine getirme sürecidir. İnovasyon, katma değer yaratması bakımından, ekonomik büyümenin kilit 
unsurlarından biridir. Gelişmekte olan ülkeler diğer ülkelere göre ekonomik alanda avantaj sağlaması açısından bilim ve teknoloji üretmek hatta ürettiği teknolojiyi ihraç etmek zorundadırlar. Bu sebeple inovasyon bir ülkenin bilim ve teknolojiyi üretmesi ve ürettiği teknolojiyi ihraç eden bir ülke konumuna gelebilmesi için etkin bir rol oynamaktadır. Gelişmekte olan ülkeler için bilim ve teknolojiyi üretmek devlet tarafindan sağlanan teknoloji politikaları ile geliştirilebilmektedir. Bu sebeple bilim ve Ar-Ge' ye önem verilmesi ve bu konuda önemli yatırımlar yapılması gerekmektedir. Bilim ve Ar-Ge kapsamında teknolojilerin geliştirilmesi açısından teknoloji geliştirme bölgelerine (teknokentler) ihtiyaç duyulmaktadır.

Fakat ülkemiz açısından Ar-Ge faaliyetlerinin büyük maliyetlere sahip olması ve bu faaliyetlerin başarısızlık riskinin yüksek olması nedeniyle birçok firma Ar-Ge faaliyetini gerçekleştirmekten kaçınmaktadır. $\mathrm{Bu}$ sebeple devlet teknokentlerde Ar-Ge faaliyeti gerçekleştirmek isteyen firmalara yönelik faaliyetlerini özendirme çabası amaciyla çeşitli istisna ve teşvikler sunarak bu firmaların faaliyetlerini gerçekleştirmek için katkı sağlamaktadır. Bu noktada ülkemizde teknokentlerde Ar-Ge faaliyetlerinin daha rahat ve daha rekabetçi bir ortamda gerçekleşebilmesi için 26.06.2001 tarihli 4691 sayılı Teknoloji Geliştirme Bölgeleri Kanunu kapsamında Teknoloji Geliştirme Bölgeleri kurulmuştur.

$\mathrm{Bu}$ süreçte teknokentlerde gerçekleştirilen $\mathrm{Ar}-\mathrm{Ge}$ faaliyetlerinin başarısızlık riskinin oluşması, Ar-Ge faaliyetlerinin uzun sürmesi ve maliyetlerinin oldukça yüksek olması bu faaliyetlerin nasıl muhasebeleştirilmesi gerektiği sorununu ortaya çıkarmıştır. Ayrıca 4691 sayılı kanunda sayılan istisna ve teşviklerin de nasıl muhasebeleştirilmesi gerektiği de tartışma konusu oluşturmuştur.

Ülkemizde genel kabul görmüş muhasebeleştirme işlemlerinde yaygın olarak MSUGT kullanılmaktadır. TMS/TFRS Tam Set'de Ar-Ge faaliyetleri sonucunda oluşan maliyetlerin ne şekilde muhasebeleştirileceği konusunda oldukça ayrıntılı düzenlemeler yer almaktadır. Fakat TMS/TFRS Tam Set'in uygulama kapsamı 6362 sayılı Sermaye Piyasası Kanunu uyarınca Sermaye Piyasası Kurulunun düzenleme ve denetimine tabi işletmelerden oluşmaktadır. Ayrıca aynı maliyetlerin muhasebeleştirilmesinde BOBİ FRS de düzenlemeler yer almaktadır. Bu standardı ise bağımsız denetime tâbi olup TMS/TFRS Tam Set uygulamayan büyük ve orta boy işletmeler uygulayabilmektedir.

Ülkemizde yaşanan bu tür sorunlardan dolayı bu çalışmada teknokentlerde faaliyet gösteren firmaların Ar-Ge faaliyetleri ile 4691 Sayılı kanun kapsamında tanınan istisna ve teşviklerin muhasebe kayıtlarını incelemek ve bu kayıtları MSUGT, TMS/TFRS Tam Set ve 
BOBİ FRS kapsamında karşılaştırmalı olarak gösterebilmek amacıyla Isparta Göller Bölgesi Teknokenti’ nde faaliyet gösteren bir firma üzerinde araştırma yapılmıştır.

Yapılan araştırma sonucunda proje kapsamında katlanılan maliyetlerin MSUGT, TMS/TFRS Tam Set ve BOBİ FRS'ye göre muhasebeleştirilmesinde kullanılan hesapların değiştiğine rastlanmıştır. TMS/TFRS Tam Set ile BOBİ FRS arasında Ar-Ge maliyetlerinin muhasebeleştirilmesi benzerlik göstermektedir. TMS-38 Maddi Olmayan Duran Varlıklar Standardı proje aşamasını araştırma safhası ve geliştirme safhası olarak ikiye ayırmış, projenin geliştirme safhasında projeyle ilgili katlanılan maliyetlerin aktifleştirileceği konusunda BOBİ FRS ile uyumludur. Fakat MSUGT' ye göre proje başlamadan önce katlanılan maliyetler aktifleştirilebilecektir. Bu durumda maliyetlerin aktifleştirilebileceği konusunda MSUGT, TMS/TFRS Tam Set ve BOBİ FRS ile farklılaşmaktadır.

\section{KAYNAKÇA}

Aleinikoff, T. A. (2014, July 19). Innovation-what, why and how for a un organisation. Oxford, 8 .

Bezirci, M. (2012). Ar-Ge Teşvikleri. İstanbul: Beta Yayınları.

Biçkes, D. M. (2011). Örgütsel öğrenme, inovasyon ve firma performansı arasındaki ilişkiler: Inovasyonun aracılık etkisine yönelik büyük ölçekli işletmelerde bir araştırma. Yayınlanmamış doktora tezi. Erciyes Üniversitesi, Sosyal Bilimler Enstitüsü, Kayseri.

BOBİ FRS. (2017, Temmuz 29). Büyük ve Orta Boy İşletmeler Iç̧in Finansal Raporlama Standardl(56). 30138 Sayılı Mükerrer Resmi Gazete.

Bulut, Ç., \& Arbak, H. (2012). İnovasyon, direnç ve iletişim; kavramsal bir tartışma. (S. Karaata, Dü.) Yenilik, Yenilesim, Inovasyon Dünyasina Bir Yolculuk, 5-19.

Çaltekin, M. (2014, Nisan 6). Teknoloji geliştirme bölgelerinde vergi ve sosyal güvenlik uygulamalarl. Erişim Tarihi: Mart 2020: http://www.pkfistanbul.com/download/TGB_Vergi_Uygulama.pdf

Drucker, P. F. (1984). Innovation and entrepreneurship. Wall Street Journal.

Elçi, Ş. (2007). Inovasyon: Kalkınmanın ve Rekabetin Anahtarı (2 b.). Tecnopolisgrup..

Eren, M. (2011). Türkiye'nin Teknolojik Gelişmesinde Teknoparklar ve Ar-Ge Desteği. İstanbul.

Gazete, R. (2011, 03 02). Kanun, 6170 Sayılı Teknoloji Geliştirme Bölgeleri Kanununda Değişiklik Yapılmasına Dair. (27872).

Güney, Z. (2010, Mart 10). Teknoparklar ve teknokentler..-Araştırma-. Erişim Tarihi: Mart 1, 2020:http://www.ziyaguney.com/index.php?option=com_content\&view=article\&id=797:tekno parklar-aratrma- \&catid $=54$ :aratrma-ve-raporlar \&Itemid $=220$

IMF. (2011). Global Trade Liberalization and the Developing Countries. 
Kendir, E., Aslantaş Ateş, B.

Kayalıdere, G. (2014). Türkiye'nin teknoloji politikalarında teknoparkların önemi ve teknoparklara yönelik vergi avantajları. Gazi Üniversitesi, Sosyal Bilimler Dergisi, I(1).

Kaynak, S. (2011). Avrupa Birliği yolunda bilim ve teknoloji bağlamında Türkiye'nin AB-27 ülkeleri karşısındaki mevcut durumu. Bilgi Ekonomisi ve Yönetimi Dergisi, VI(2).

Kızıltaş, M. İ. (2006). The dilemma of flexibility in the spatial development of science parks the case of metu-technopolis. A Thesis Submitted to The Graduate School of Natural and Applied Sciences of Middle East Technical Unıversity.

OECD. (2005). Guidelines For Collecting End Interpreting Innovation Data, Oslo Manuel (Third Edition b.). Paris: OECD.

Öner, M. A. (2006). Ar-Ge Yönetimi (1. b.). Boğaziçi Üniversitesi.

Porter, M. (1990). The Compititive Advantage of Nations. Macmillian.

Rogers, E. M. (1971). Diffusion of Innovation (Third Edition b.). New York.

Rosenfeld, R. M. (2012). Innovation. Otolaryngology-Head and Neck Surgery 146(1), 1.

Tan, M., \& Erdem, T. (2010). Türkiye'de Ar-Ge Teşvikleri. İstanbul: İstanbul Ticaret Odası Yayınları.

TMS-20 . (2005, Kasım 1). Devlet Teşviklerinin Muhasebeleştirilmesi ve Devlet Yardımlarının Açıklanması Standardı. 25983 sayılı Resmi Gazete.

TMS-23 . (2015, Kasım 9). Borçlanma Maliyetleri Standardı. 25988 Sayılı Resmi Gazete.

TMS-38. (tarih yok). Erişim Tarihi: Mart 5, 2020:http://www.kgk.gov.tr/Portalv2Uploads/files/DynamicContentFiles/T\%C3\%BCrkiye\%20 Muhasebe\%20Standartlar\%C4\%B1/TMSTFRS2011Seti/TMS38.pdf

Tuncer, S. (2010). Türkiye'de Ar-Ge Teşvikleri ve Uygulaması. Yaklaşım Yayımcılık.

26.12.1992 tarihli ve 21447 Mükerrer Sayılı Resmi Gazete'de yayımlanan 1 Sira No.lu Muhasebe Sistemi Uygulama Genel Tebliği. (tarih yok).

3065 Sayılı Katma Değer Vergisi Kanunu. (1984, 11 2). 24(18563), 47. Resmi Gazete.

4691 Sayılı Kanun Metni. (2001, Temmuz 6). 24454 Sayılı Resmi Gazete.

5520 Say11 Kurumlar Vergisi Kanunu. (2006, Haziran 21). 26205 Sayılı Resmi Gazete.

6170 Sayılı Teknoloji Geliştirme Bölgeleri Kanununda Değişiklik Yapılmasına Dair Kanun. (2011, Mart 2). 